Commentary

\title{
Plowshares or Swords? Fostering Common Ground Across Difference
}

\author{
Karen Trapenberg Frick \\ Department of City and Regional Planning, College of Environmental Design, University of California, Berkeley, Berkeley, \\ CA 94720, USA; E-Mail: kfrick@berkeley.edu
}

Submitted: 26 September 2017 | Accepted: 28 September 2017 | Published: 31 October 2017

\begin{abstract}
With political polarization challenging forward progress on public policy and planning processes, it is critical to examine possibilities for finding common ground across difference between community participants. In my research on contentious planning processes in the United States, I found four areas of convergence between participants over transportation policy and process related to public process and substantive matters. These convergences warrant planners' attention because they united stakeholders coming from different vantage points.
\end{abstract}

\section{Keywords}

agonism; agonistic ethos; common ground; conflict resolution; sustainability planning

\section{Issue}

This commentary is part of the issue "Social Ecology of Sustainability", edited by Stephen Wheeler (University of California, Davis, USA), Christina Rosan (Temple University, USA) and Bjoern Hagen (Arizona State University, USA).

(C) 2017 by the author; licensee Cogitatio (Lisbon, Portugal). This article is licensed under a Creative Commons Attribution 4.0 International License (CC BY).

\section{Introduction}

Political polarization in the United States is hindering progress in public policy and meaningful engagement at all levels of government. How do legislative requirements-like those for regional sustainability planning in California-help or hinder meaningful public engagement? What are the biggest challenges and opportunities for improving engagement?

Public process design is critical when participants are ideologically divided and do not trust each other or the public agencies in charge. In these cases, it is important to seek common ground on contentious, ideologically charged issues connected to sustainability. For example, all participants in a process may not agree on whether climate change exists, but they might agree that electric and hybrid vehicles should pay their fair share of road costs. They may not be able to agree on whether highdensity development is beneficial, but they could pursue joint fact-finding to assess its effects on property rights and values, gentrification and displacement, and public services like schools, police and fire departments.
During my research on contested sustainability planning and infrastructure processes, unexpected areas of convergence emerged in the San Francisco Bay Area, the Atlanta, Georgia region, and the City of Gainesville, Florida (Trapenberg Frick, 2013, 2016, forthcoming; Trapenberg Frick, Weinzimmer, \& Waddell, $2015)^{1}$. These convergences arose despite staunch disagreement over which planning strategies would support prosperity in these areas. In the Bay Area, the Metropolitan Transportation Commission and the Association of Bay Area Governments held meetings aimed at developing the region's first Sustainable Communities Plan, known as Plan Bay Area and adopted in 2013. Tea Party and property rights activists came out in force to block these meetings and were not alone in their opposition. Plaintiffs from across the political spectrum filed four lawsuits against the plan: two had connections to Tea Party and property rights activists; one was brought by the building industry; and one was filed by environmental organizations. In the progressive stronghold of Marin County, citizens not affiliated with Tea Party or property rights groups opposed requirements associated with

${ }^{1}$ In addition to related citations by the author, this article builds on "Common Ground" in ACCESS magazine at https://www.accessmagazine.org/fall2015/the-access-almanac-common-ground and "Can Planners Find Common Ground with Tea Party and Property Rights Activists on Means even if They Don't Agree on Ends?" in the California Planning and Development Report at http://www.cp-dr.com/node/3536 
higher density development planning if cities wished to access regional funds.

In the Atlanta region, Tea Party and property rights activists led the opposition to a 2012 regional sales tax proposal. The measure would have dedicated half of the new tax revenue to public transit projects. A coalition of strange bedfellows emerged: Sierra Club and National Association for the Advancement of Colored People leaders joined the opposition, in part because they felt the proposed transit projects were not the ones the area needed. Although it is hard to say what effect the coalition had on the measure, the tax measure failed decisively with 63 percent of voters in opposition.

A loose coalition also emerged in Gainesville between Tea Party and property rights activists and some residents from East Gainesville, a lower-income African American neighborhood. They argued that the City's proposed Bus Rapid Transit line was too costly and unnecessary. The BRT line was initially proposed for funding in a county-based transportation sales tax before the voters in 2012. Due partly to this opposition, the county dropped the transit line from funding consideration in tandem with other transit projects.

\section{Areas of Common Ground}

I found four areas of convergence between participants over transportation policy and process in these areas. These convergences warrant planners' attention because they united stakeholders coming from different vantage points.

First, some conservative activists in Atlanta supported vehicle-miles-traveled (VMT) fee as a replacement for the gas tax if major administrative and privacy challenges were overcome. They argued that drivers of electric and hybrid vehicles are not paying their full share of transportation system costs. Progressives have often advocated for this fee transition as well with the hope that funding could be directed to transit, bicycle, and pedestrian projects.

Second, conservative activists in both the Bay Area and Atlanta questioned the wisdom of running costly rail lines in low-density areas. Their arguments aligned with those of environmentalists and other progressives who would rather have seen transit investment in central cities for equity and efficiency reasons, and with academic researchers who caution that mass transit needs a sufficient density of residents and jobs to generate significant transit ridership. In Gainesville likewise some conservative activists supported improved bus service for low-income residents for reasons related to equity and cost.

Third, conservative activists in the Bay Area and Atlanta regions questioned the authenticity of the planning process, suggesting that planners merely went through the motions to arrive at a predetermined outcome. Progressive activists in those regions and planning scholars have had similar concerns, debating for decades whether large-scale planning processes with public meetings and hearings are meaningful formats for public input.

Fourth, activists across the political spectrum opposed the 2012 sales tax proposal in Atlanta because they viewed it as a regressive across-the-board tax rather than a user fee. Planning scholars similarly caution against sales taxes to fund transportation infrastructure. They argue that in states where local sales taxes for transport run rampant, states should move towards a user fee approach. This could include gas taxes, tolls, congestion pricing, parking charges and transit fares. Federal gas tax revenue, a major funding source, has declined significantly as the U.S. Congress has not increased the tax since 1993. Local areas have looked to increasing sales taxes through voter approved ballot measures to shore up the difference. In contrast to the Atlanta case of opposition, some Bay Area environmental activists have reluctantly supported sales tax increases over the years if they included a broad-based package of transportation modes.

\section{Opportunities}

When the public is ideologically divided over planning issues, a way to move forward could be by seeking areas of common ground like the ones outlined above. As one Tea Party leader advised me, "When the left and right sits down and actually communicates with each other, many times both sides are amazed that there is agreement on issues. You just have to be able to respect the fact [that] both sides have a right to believe the way they do politically and not focus on it. If you disagree on $90 \%$ of the issues, you will be much more successful if you try to find a way to work together on the $10 \%$ you agree on."

Planners could draw from the theory of agonism to reframe their approach to civic engagement. I draw inspiration from political theorists Chantal Mouffe and William Connolly's key scholarship in this area. In agonistic contexts, participants come to consider their opponents as legitimate adversaries rather than as enemies unworthy of engagement. In such moments, people maintain their core values and identities (Mouffe, 2013). As a result, an agonistic ethos of respect may emerge between otherwise divergent citizens (Connolly, 1995). I find this ethos and framing opens up opportunities for activists to discuss potential common ground across difference even if in limited ways or agreeing to disagree. As they voluntarily participate in deliberations, they can seek to redirect or exit the discussions. Critically important to activists is retaining their primary identities to remain legitimate to their side of the aisle.

Mouffe's interest in agonism stems from her critiques of the theory of communicative rationality which she argues privileges consensus and speech practices devoid of emotions. This situation in turn stifles passionate debate and excludes dissenting views. Some planning scholars consider agonism as an antidote to communicative planning theory which they argue masks power dynamics and 
reinforces existing societal inequities (for a summary of debates, see Bond, 2011 also see Innes \& Booher, 2015). In divided cities, for example, planning scholars look to agonism in tandem with other strategies as a way forward for transitioning city actors to living with difference (Bollens, 2012, p. 239; Gaffikin \& Morrisey, 2011). Other scholars argue that agonism and communicative practices can co-exist as planning processes evolve (Fougère \& Bond, 2016; Inch, 2015; Legacy, 2016).

One way to set the stage for agonistic engagement and inform community negotiations would be for activists and planners to jointly conduct analyses that examine, for example, the range of potential property rights impacts (Jacobs \& Paulsen, 2009) and full lifecycle costs of projects and plans. These analyses might underscore and/or uncover critical issues that warrant further attention and, thus, bolster continued activist involvement. Planning-related policy efforts and legislation could recommend such analyses be undertaken as part of larger processes that include public engagement. To aid deliberations and mutual understanding, these recommendations could include independent mediators trained in conflict negotiation and resolution as well as other techniques including in-depth interviews with key stakeholders and non-traditional activities such as site visits and walking tours outside of standard public meetings (e.g., Forester, 2009). Public agency planners and elected officials' participation is critical if they or proposed plans seem likely under attack be it from conservative or progressive and environmental activists. While an agonistic ethos might emerge between stakeholders, the gate keepers of plan making (public agency officials) could elect to dismiss or not incorporate mutual understandings stemming from such activities unless they engage in reframing their enemy Other into at least an adversary.

Pilot funding through public or other sources could be provided to implement agonistic processes and examine their strengths and weaknesses. Pilots and evaluation would be worth the cost if agonistic relations between divergent actors can be fostered and community engagement is improved-potentially paying dividends by also laying the groundwork for activist relations on other planning endeavors.

In sum, it is worthwhile to establish the long-term objective of transitioning from highly antagonistic, counterproductive encounters to interactions of agonistic debate. Such an objective-with its focus on convergence among opposing parties-may serve states, regions and localities well as they assess their public participation and planning requirements, particularly those related to contentious issues like sustainability and climate change.

\section{Conflict of Interests}

The author declares no conflict of interests.

\section{References}

Bond, S. (2011). Negotiating a 'democratic ethos' moving beyond the agonistic-communicative divide. Planning Theory, 10(2), 161-186. doi:10.1177/ 1473095210383081

Bollens, S. A. (2012). City and soul in divided societies. Abingdon: Routledge.

Connolly, W. E. (1995). The ethos of pluralization. Minneapolis, MN: University of Minnesota Press.

Forester, J. (2009). Dealing with differences. Dramas of mediating public disputes. New York: Oxford University Press.

Fougère, L. \& Bond, S. (2016). Legitimising activism in democracy: A place for antagonism in environmental governance. Planning Theory, p.1473095216682795. doi:10.1177/1473095216682795

Gaffikin, F., \& Morrissey, M. (2011). Planning in divided cities. New York: John Wiley \& Sons.

Inch, A. (2015). Ordinary citizens and the political cultures of planning: In search of the subject of a new democratic ethos. Planning Theory, 14(4), 404-424. doi:10.1177/1473095214536172

Innes, J. E., \& Booher, D. E. (2015). A turning point for planning theory? Overcoming dividing discourses. Planning Theory, 14(2), 195-213. doi:10.1177/ 1473095213519356

Jacobs, H. M., \& Paulsen, K. (2009). Property rights: The neglected theme of 20th-century American planning. Journal of the American Planning Association, 75(2), 134-43. doi:10.1080/01944360802619721

Legacy, C. (2016). Is there a crisis of participatory planning? Planning Theory. doi:10.1177/ 1473095216667433

Mouffe, C. (2013). Agonistics: Thinking the world politically. London: Verso.

Trapenberg Frick, K. (2013). Actions of discontent: Tea Party and property rights activists pushing back against regional planning. Journal of the American Planning Association, 79(3), 190-200. doi:10.1080/ 01944363.2013 .885312

Trapenberg Frick, K. (2016). Citizen activism, conservative views \& megaplanning in a digital era. Planning Theory and Practice, 17(1), 93-118. doi:10.1080/ 14649357.2015.1125520

Trapenberg Frick, K. (forthcoming). No permanent friends, no permanent enemies: Agonistic ethos, tactical coalitions and sustainable infrastructure. Journal of Planning Education and Practice.

Trapenberg Frick, K., Weinzimmer, D., \& Waddell, P. (2015). The politics of sustainable development opposition: State legislative efforts to stop the United Nation's Agenda 21 in the United States. Urban Studies, 52(2), 209-232. doi:10.1177/ 0042098014528397 


\section{About the Author}

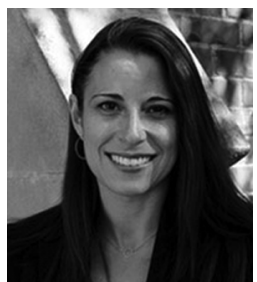

Karen Trapenberg Frick, PhD is Assistant Adjunct Professor in the Department of City and Regional Planning at University of California, Berkeley, Director of the University of California Transportation Center, and Assistant Director of the University of California Center on Economic Competitiveness in Transportation. Her current research focuses on the politics of major infrastructure projects and conservative views about planning and planners' responses. She also is the author of the book Remaking the San Francisco-Oakland Bay Bridge: A Case of Shadowboxing with Nature (Routledge/Taylor \& Francis, 2016) and teaches city planning and transportation courses at UC Berkeley. 